concerned-the contractors, the local authority, the consulting engineers, the National Building Agency and the Building Research Station-but the main brunt of criticism falls on the machinery within the industry for drafting new codes of building practice. The structural faults of the Ronan Point type of system. built block are now familiar. The joints between wall and floor panels have little strength, and in addition the load-bearing system of the whole block makes no provision for the failure of one of its members. So the destruction of any single load-bearing panel-by fire, explosion or wind damage-is liable to set in train a progressive collapse from top to bottom of the building.

Allowances for wind loading were strongly criticized by the tribunal. Ronan. Point was designed to withstand a wind speed of $63 \mathrm{~m} . \mathrm{p} . \mathrm{h}$., yet winds of more than 100 m.p.h. could be expected at least once in the predicted sixty years' life of such a block. This would correspond to a wind pressure at the top of Ronan Point of more than twice that actually envisaged in its design. This is one of the ways in which the tribunal says that the builders were let down by the ministry's advisory services. But Dr F. G. Thomas, Deputy Director of the Building Research Station, gave a contrary view last week. Newer estimates of wind speeds in London, he said, put the likely maximum gust nearer to 90 m.p.h. He also described work at the BRS which showed that in cities the necessarily turbulent flow of wind reduces the total force it can exert against a building. Given, in addition, that the $63 \mathrm{~m} . \mathrm{p} . \mathrm{h}$. figure relates to wind velocity maintained for one minute, while the $90 \mathrm{~m} . \mathrm{p} . \mathrm{h}$. figure refers to peak gusts, Dr Thomas felt that system blocks were in little danger of being blown over.

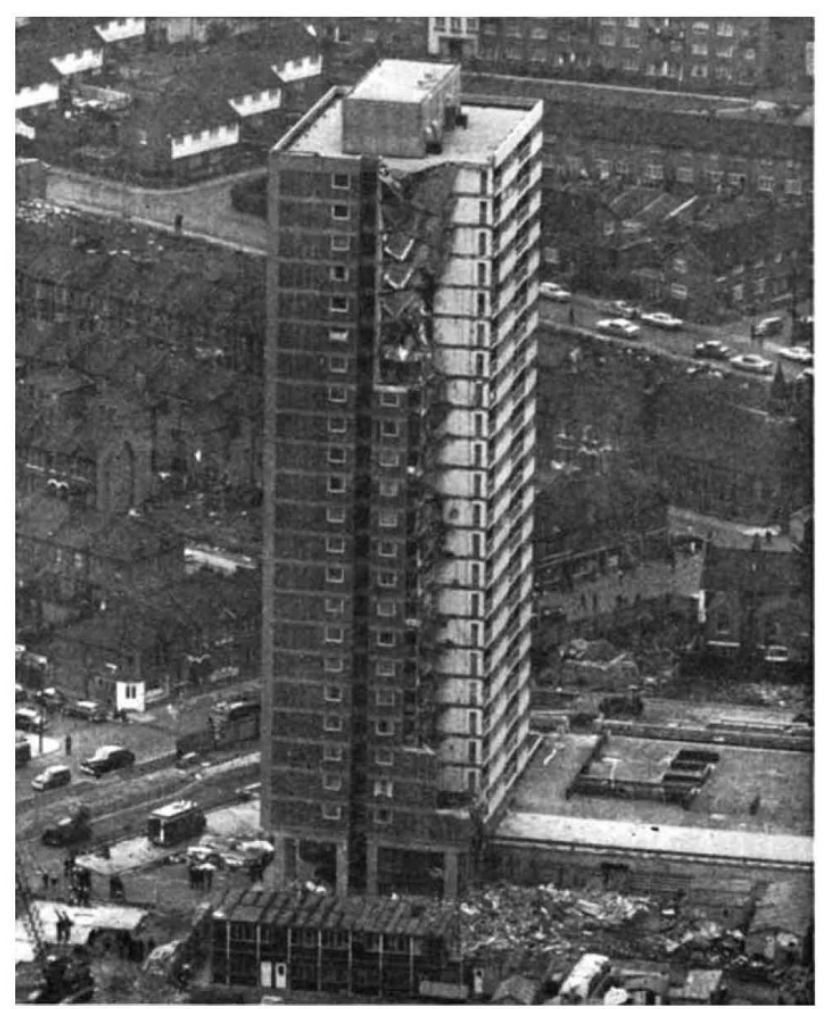

Ronan Point.
The tribunal felt that the building professions in Britain were seriously at fault in committing themselves wholesale to system built blocks without making a full analysis of the structural problems involved. The BRS was specifically criticized. A senior member of its staff served as the English representative on the Comité Européen du Béton which in 1967 published (in French) a comprehensive report on the design of system buildings. This report spelled out the danger of progressive collapse in the following words: "One can hardly over-emphasize the absolute necessity of effectively joining the various components of the structure together in order to obviate any possible tendency for it to behave like a "house of cards'. . . In this respect it would appear to be of major importance to install mechanically continuous steel ties interconnecting opposite walls or facades and providing safeguards for all the vertical panels".

The tribunal claims that in spite of the obvious relevance of this report, it was not followed up by the BRS, and not made available in English until July 1968. Dr Thomas denied this charge of laxity last week. The report, he said, was circulated promptly on publication by the BRS to the Codes of Practice Committee which was at that time considering the design of joints in large panel structures. Members of the committee translated the report themselves, and it was available in English by September 1967.

The BRS now claims that it gave warning of the hazards of joints in system blocks to a symposium of the Institute of Structural Engineers in 1966, and since then it has been conducting research on the subject. The BRS agreed that the additional fault behind the Ronan Point disaster, the lack of any safety factor in the load-bearing shell, had been given little attention in Britain.

Although public discussion has so far centred on the reasons for the collapse of this block of flats and on the devices which may be used to protect those still standing, it is still possible that attention may yet be directed to this question of whether a government which takes an active part in planning and fostering new techniques of building can also adequately keep its contractors up to the mark.

\section{WEED CONTROL Who Controls the Controllers?}

The ninth British Weed Control Conference, which opened at Brighton this week, found the British herbicide industry in a confident mood. Output has trebled in six years and exports are healthy but, more important, the industry feels that it is now in a position to bring about a transformation of agricultural practice.

In Britain a few farmers are already growing corn without use of the plough, by using herbicides of the bipyridyl type to kill stubble and weeds after the harvest. Apparently the mat of dead vegetation protects the soil against erosion during the winter and provides ideal conditions for the sprouting of the new crop in the spring. As well as the herbicides, the method requires a regimen of fungicides to control plant disease. At first sight, arable farming without the plough seems a violation of natural law. But in one sense the method is a return to the natural state, to the forest floor conditions which prevailed before man 
became an agricultural animal. At best, it seems, farmers are faced with a choice of evils. The labour force in agriculture declines by five per cent a year, and productivity per man must increase. If ploughs are to be retained, then tractors must become larger, fields must become larger and hedges must come down, which itself is a violation of the countryside as it is.

Criticism from conservationists has been quite deeply felt within the pesticide industry, which is on its own initiative lobbying the British Government to introduce a compulsory scheme for the registration of pesticides. The present scheme is voluntary. But manufacturers have shown little enthusiasm for the idea that defoliants should be subject to the terms of the Geneva Convention on biological warfare. Several defoliants of British invention are apparently being used in Vietnam. The current safety regulations cope fully with the toxicity of pesticides but take no account of persistence. Most chemicals are soon destroyed by bacteria in the soil, but "Picloram", a herbicide produced by Dow Chemical, is exceptional in its resistance to bacterial attack. There is therefore a risk that it might accumulate in waterways and spread to untreated ground. "Picloram" is being withdrawn from use as stocks run out, and moves are afoot to add a persistence clause to the pesticide regulations.

\section{SI UNITS}

\section{Recalcitrant Physicists}

BRITISH physicists, like engineers and chemists, seem reluctant to adopt the full-blooded version of the international system (SI) of units. Attempts were made to define the areas where there is fundamental disagreement at a meeting held last week by the Royal Society to discuss the use of SI units in physies.

Professor M. J. Lighthill, who ran the meeting, pleaded that physicists should be prepared to make some concessions for the sake of establishing a coherent common language for communication between scientists from different countries and from different disciplines. He realized that in some fields, like nuclear physics and astrophysies, the orders of magnitude involved are such that SI units are inappropriate, and that non-dimensional systems of units are so useful that they should not be abandoned, but he thought that in most other fields SI units could bo successfully incorporated.

Professor F. C. Frank from Bristol agreed that the present system of units should be reformed and stressed that half measures, like the use of the $\mathrm{kg}$-force instead of the lb-force, should be avoided. He thought that objections to particular SI units on the grounds of current familiarity or because their orders of magnitudes are less convenient than those of conventional units did not carry much weight. The SI unit cannot differ by more than a factor of 10 from the conventional unit, because a thousand times or a thousandth of each unit is another allowed unit. But valid objections could be made to the use of SI units in electromagnetism, he thought. Physically the quantities magnetic field and magnetic induction, and electric field and displacement, are similar, but they have different SI units. Another objection to SI is that in high precision work physical quantities like volume can be compared to precisions of parts in $10^{7}$, but can be determined in terms of the basic SI unit to precisions of only parts in $10^{4}$.

Most physicists work in a particular field and do not need to communicate outside this field, and Professor R. G. Chambers, also from Bristol, agreed that different dialects should be allowed. He defended the spectroscopists' use of the Angstrom and $\mathrm{cm}^{-1}$ which are not recognized metric units. The Inter-Union Commission for Spectroscopy which represents the views of most spectroscopists, issued a statement in July in support of the Angstrom and $\mathrm{cm}^{-1}$. Some members of the commission recommended the indefinite preservation of these units. Crystallographers also like the Angstrom because it is a convenient unit for interatomic distances and chemical bond lengths.

Sir Harrie Massey, chairman of the Council for Scientific Policy, hoped that scientists writing books or contributing to journals would not be forced to use SI units exclusively. If an authoritarian editorial policy were adopted, he warned, authors would probably send their manuscripts to the United States. A spokesman for the Royal Society said that, in the pamphlet it has prepared on the use of signs, symbols and abbreviations in scientific journals, it recommends that editors should insist on the use of the recommended symbols for physical quantities, and the definition once in a paper of any non-SI unit used, and that they should progressively discourage the use of non-SI units.

The question of the units to be used for pressure remains a vexed one and Dr Fielden from the British Standards Institution explained that the BSI would like to see the $\mathrm{N} / \mathrm{mm}^{2}$ or $\mathrm{MN} / \mathrm{m}^{2}$ as the unit of pressure. Because some industries were already using the hbar (10 N/mm ${ }^{2}$ ), however, the institute would probably issue standards showing both units for some time, hoping that the basic unit would gradually be accepted.

\section{EPIDEMIOLOGY \\ Unpredictable Bug}

Hong Kong influenza, now making its debut in Europe and the United States of America, has spread rapidly since it originated in Hong Kong and neighbouring areas of China in mid-July. Nobody can predict if and when a large-scale epidemic is likely to break out in Britain, although previous experience of influenza epidemics points to late December and early January as "target" months, and similar dates have been quoted for an expected increase in the incidence of influenza in the United States. Reactions range from cheerful optimism to great consternation-particularly on the part of Mr Eric Moonman, chairman of the Labour Party's Science and Technology Committee, who is questioning the Government's plans to deal with an epidemic.

Because the new strain of virus differs quite considerably from the older A2 strain which it has displaced, existing supplies of vaccine against A2 Singapore provide very little protection against Hong Kong influenza. Consequently, three British drug companies are manufacturing new vaccine for immunization-in the first instance of the aged and chronically sick, in accordance with instructions from the Ministry of Health (Department of Health and Social Security). Beecham's Research Laboratories went into production at the end of August and started to distribute vaccine about 2 weeks ago. Crookes Laboratories Ltd also 